International Journal of Multidisciplinary Research AND ANALysis

ISSN(print): 2643-9840, ISSN(online): 2643-9875

Volume 04 Issue 12 December 2021

DOI: 10.47191/ijmra/v4-i12-11, Impact Factor: 6.072

Page No.- 1841-1846

\title{
The Impact of the Rupiah/Dollar Exchange Rate, Inflation Against the SBI Interest Rate During the New Normal Period
}

\author{
Lusi Elviani Rangkuti ${ }^{1}$, Farida Khairani Lubis ${ }^{2}$, Rismawati ${ }^{3}$ \\ 1,2,3 Universitas Islam Sumatera Utara
}

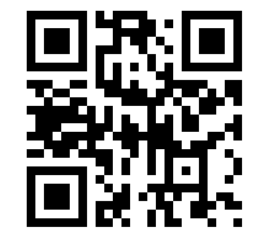

ABSTRACT: The Covid 19 pandemic has changed the order of Indonesian society and even the world; to prevent the spread of this virus, a new lifestyle or "New normal" is implemented, in which people can still do activities outside the home while adhering to health protocols. As a result of the economic sector's pandemic condition, the rupiah exchange rate against the dollar fell, as did inflation and interest rate values.

The goal of this research is to determine the impact of the Rupiah exchange rate, inflation, and interest rates during the New Normal Period. The New Normal period, as we know, begins in early June 2020, so researchers plan to collect data from June 1, 2020 to March 31, 2021. The information used is skunder data. This study used saturated sampling or a census sample, which is a technique for determining "samples where all members of the population are used as samples." The research method used is quantitative research. The test is a multiple linear regression analysis that begins with a traditional assumption test that includes a normality test and a multicollinearity test.

The findings revealed that during the New Normal period, the rupiah/dollar exchange rate had a positive and significant effect on SBI interest rates. During the New Normal period, inflation has a positive and significant impact on SBI interest rates. During the New Normal, the Exchange/Dollar Rate and the Inflation Rate both have a positive effect on the SBI Interest Rate.

KEYWORDS: Rupiah/Dollar Exchange Rate, Inflation, and SBI Interest Rate

\section{A. INTRODUCTION}

Corona Virus Disease 2019 (covid-19) is becoming more common in Indonesia. The Covid 19 pandemic has changed the order of Indonesian society and even the world; in order to prevent the spread of this virus, a new lifestyle or "New normal" is enacted in which people can still do activities outside the home while adhering to health protocols such as wearing masks, washing their hands frequently with soap, and keeping their distance and avoiding crowds. The goal of this "new normal" is to keep people productive while also protecting them from Covid-19 transmission during a pandemic. The spread of this virus has an impact not only on health but also on the global economy, particularly in Indonesia.

As a result of the economic sector's pandemic condition, the rupiah exchange rate against the dollar fell, as did inflation and interest rate values. Social constraints and community activities cause scarcity in the fulfillment of daily needs to the needs of medical devices. This causes the price stability of an item to change. The greater the scarcity of a community's needs and the greater the demand for those needs, the higher the value or price of the goods.

The following graph depicts data on the development of rupiah / dollar rates before and after the covid-19 pandemic, as published on the official website of Bank Indonesia using Jakarta Interbank Spot Dollar Rate (Jisdor) data:

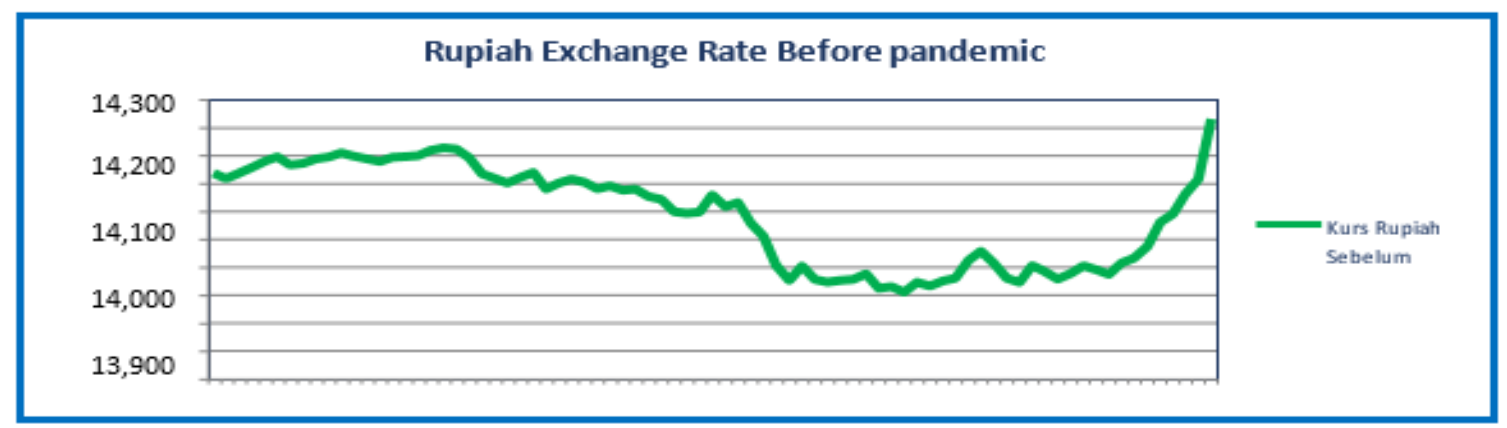

Figure 1 : Tthe Rupiah exchange rate prior to the pandemic. 
The Impact of the Rupiah/Dollar Exchange Rate, Inflation Against the SBI Interest Rate During the New Normal Period

According to the graph in Figure 1 above, the data shows how the rupiah moved from November 7, 2019 to February 28, 2020, which is the time before the announcement of the first patient affected by Covid-19." Throughout November 2019, the rupiah exchange rate fluctuated between Rp.14,000 and Rp.13,000. It then strengthened against the US dollar in January 2020, fluctuating between Rp.14,000 and Rp.13,000. The rupiah weakened again after the middle of February 2020 until the end of February 2020. This is due to the widespread presence of coronaviruses, though no official statement has been issued by the Ministry of Health.

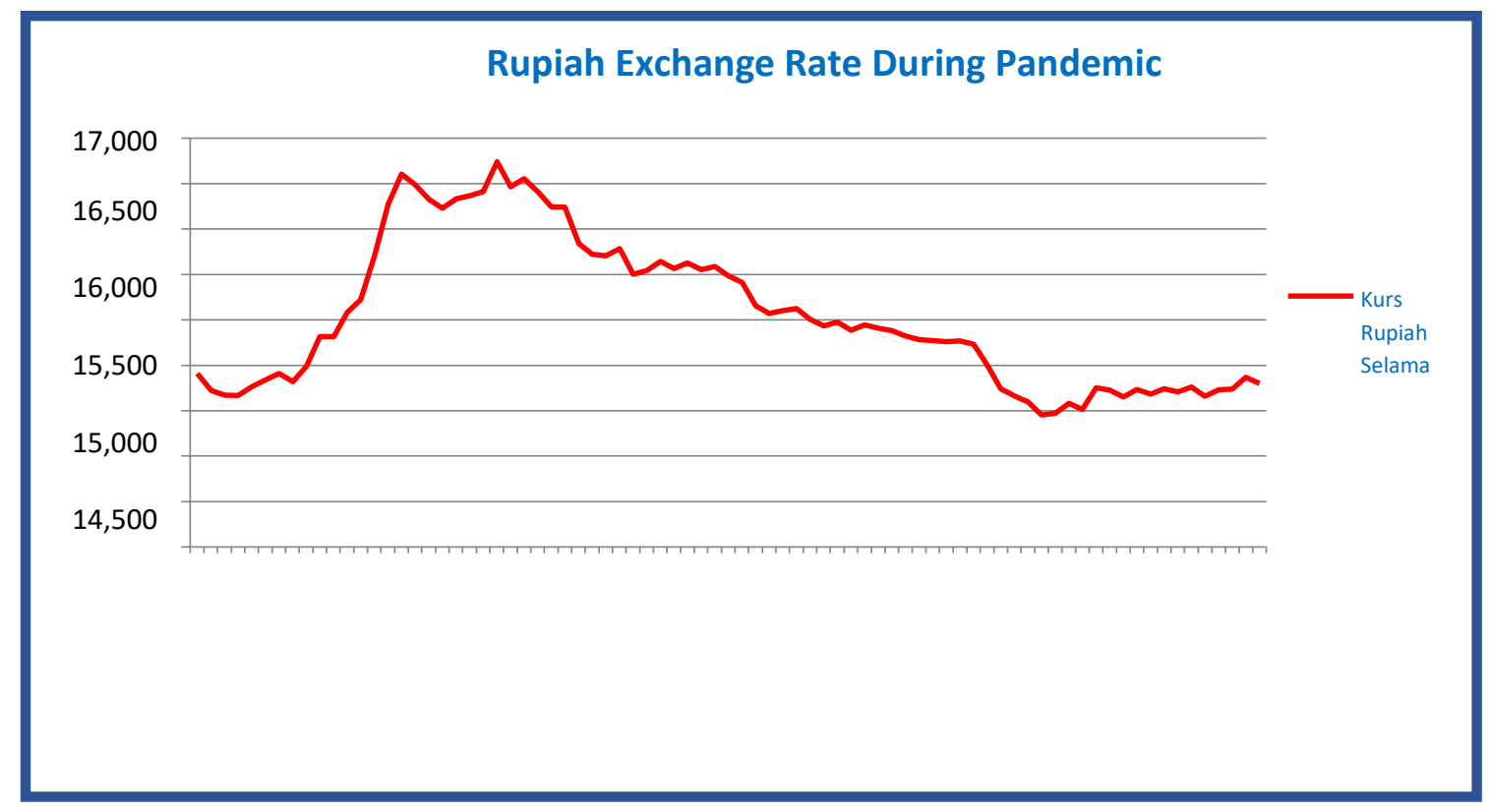

Figure 2. Rupiah Exchange Rate During Pandemic

Based on the graph in Figure 2, we can see that beginning on March 2, 2020, the day the first patient case of Covid-19 was announced, the rupiah weakened to its peak around April 2, 2020, the rupiah was at its weakest point, touching Rp. 16,741, - for one US dollar. This could happen as a result of business and economic people in Indonesia having doubts about the Indonesian government's ability to win Covid-19. The same was stated by Hanggoro (2020), who stated that the rupiah exchange rate against the US dollar fell from a level of Rp13,000s to Rp16,000 per US dollar during the last week of March 2020, and that this weakness was related to the pessimistic attitude.

One of the macroeconomic consequences of the spread of Covid 19 is the occurrence of inflation in Indonesia and even around the world. According to the data, there was 2.96 percent inflation in March 2020, with an increase in the price of gold jewelry and some food prices that experienced a fairly significant increase.

The policy of enactment of the "New Normal" period initially brought a breath of fresh air to the Indonesian economy because the community began to carry out activities that can revive the economy, but this did not happen as expected. Where the economy is still crawling forward does not correspond to the initial expectations applied during the "New Normal" period. Externally, market concerns remain due to predictions from the United States Central Bank (The Federal Reserve / Fed) to keep the benchmark interest rate at a low level, with the Federal Funds Rate at its lowest since 2015 of 0-0.25 percent.

Based on the above description, the study The Effect of Rupiah / Dollar Exchange Rate, Inflation on SBI Interest Rates During the New Normal Period" was carried out.

\section{B. PROBLEM FORMULATION}

Based on the context of the preceding problem, the formulation of the research problem is as follows:

1. Weakening exchange rate against the dollar during the pandemic, which continued during the "New Normal" period in Indonesia.

2. Inflation in Indonesia from the time of the Covid 19 virus's spread until the "New Normal" period

3. Value of low interest rates (BI Rate). 
The Impact of the Rupiah/Dollar Exchange Rate, Inflation Against the SBI Interest Rate During the New Normal Period

\section{THEORY'S FOUNDATION}

The exchange rate

According to Yoopi (2004: 36), the exchange rate or exchange rate (foreign exchange rate) is the price of one country's currency relative to another country's currency. Because this exchange rate includes two currencies, the equilibrium point is determined by both currencies' supply and demand sides. The price of one currency against another, or the value of one currency against another, is referred to as the exchange rate.

\section{Factors Influencing Exchange Rates/Exchange Rates}

According to Pure (2010:6), the following factors influence the exchange rate:

1. Inflation rate disparity between two countries

The increase in the value of state imports of foreign goods and services caused by a large increase in inflation that necessitates large amounts of foreign exchange to pay for previously completed import transactions. This is what causes an increase in the number of foreign exchange requests, which affects the country's exchange rate, causing the country's exchange rate to weaken. 2. The difference in interest rates between two countries Differences in interest rates between countries influence changes in the amount of demand and supply of money in the domestic money market. While the relation to stocks is that a relatively sharp increase in the US\$ exchange rate against the rupiah will have a negative impact on issuers who have debt in dollars and sell their products locally.

\section{Inflation}

Inflation is defined as a general and continuous increase in prices. Inflation cannot be defined as a price increase in one or two goods unless the increase is widespread (or results in a price increase) in other goods (Bank Indonesia). Inflation, as defined by Hamilton (2001), is an economic situation in which the money supply grows "faster" than the production of goods and services in the same economy. Changes in the price index can be used to calculate the inflation rate (consumer price index, wholesale price index, producer price index etc.). According to Essien (2005), the consumer price index (CPI) measures the representative basket prices of goods and services purchased by consumers.

\section{Interest Rates at SBI}

The interest rate, according to Sunariyah (2011:82), is expressed as a percentage of the principal money per unit of time. Interest is a percentage of the debtor's source price that is paid to the debtor. The unit of time is usually expressed in years (one year of investment), but it can be less than one year. Mishkin (2008) defines interest rates as the cost of borrowing or the price obtained on a given loan.

\section{FRAMEWORK OF CONCEPTS}

This study employs two (two) macroeconomic variables that influence interest rates, namely the rupiah / US dollar exchange rate and inflation. Each independent variable's relationship to interest rates can be explained as follows:

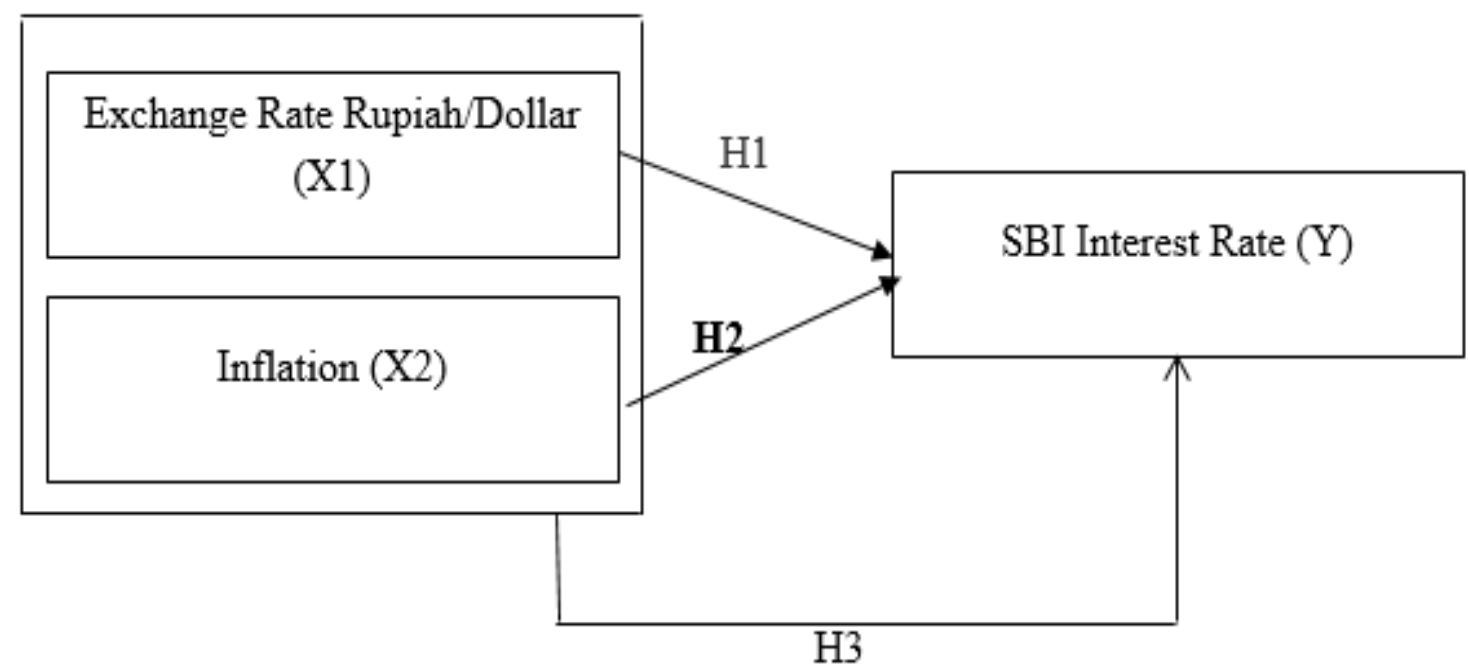

Figure.3 : Analysis of the Influence of the Rupiah Exchange Rate and Inflation on SBI Interest Rates 
The Impact of the Rupiah/Dollar Exchange Rate, Inflation Against the SBI Interest Rate During the New Normal Period

\section{METHODS OF RESEARCH}

\section{Population}

Population in the study" inflation, rupiah/US dollar exchange rate, SBI interest rate from June 1, 2020 to March 31, 2021

2. Sample

This study's sample was drawn using saturated sampling or census sampling, which is a sample selection technique in which all members of the population are used as samples. Based on these criteria, a total of 117 samples were obtained from June 1,2020 to March 31, 2021.

The following criteria were used by researchers to determine the data collection period from June 1, 2020 to March 31, 2021 :

a. There was inflation, the Rupiah/US Dollar exchange rate, and the constant and highly volatile SBI interest rate during the research period.

b. Inflation, rupiah/US dollar, and SBI interest rates experienced high volatility during the research period as a result of the global financial crisis and the bank's policy to maintain economic stability.

The structural equation model of the study is as follows:

$$
Y=a+b 1 X 1+b 2 X 2+e
$$

Information:

$Y=S B I$ Interest Rate

$\mathrm{X} 1$ = Inflation

X2 = Rupiah/USD Exchange Rate

$\mathrm{a}=$ Constant

b1,2 = coefficient for $\mathrm{X} 1, \mathrm{X} 2$

$\mathrm{e}=$ Standard error

\section{E. RESULTS AND DISCUSSIONS}

\section{Testing Hypotheses}

1. Partial hypothesis test (Test $t$ )

Individual variable significance tests with significance levels of $5 \%$ or 0.05 are used to determine the partial or absence of influence between independent and dependent variables. This study's preliminary test results are as follows:

\begin{tabular}{|c|c|c|c|c|c|c|}
\hline \multirow{2}{*}{\multicolumn{2}{|c|}{ Model }} & \multicolumn{2}{|c|}{ Unstandardized Coefficients } & \multirow{2}{*}{$\begin{array}{l}\text { Standardized } \\
\text { Coefficients } \\
\text { Beta }\end{array}$} & \multirow[b]{2}{*}{$\mathrm{t}$} & \multirow[b]{2}{*}{ Sig. } \\
\hline & & B & Std. Error & & & \\
\hline \multirow[t]{3}{*}{1} & (Constant) &,- 504 & ,211 & & $-2,383$ & 023 \\
\hline & KURS & 8,3865 & ,000 & 637 & 6,084 & 032 \\
\hline & INFLASI & ,697 & 126 & ,580 & 5,540 & 025 \\
\hline
\end{tabular}

a. Dependent Variable: SBI

Source: SPSS Data Processing Results

According to the Table, the sig values of each partially independent variable lead to different conclusions, such as:

$\mathrm{H} 1$ : Variable Exchange Rate has a sig value of 0.032 , which indicates that it has a positive and significant effect on the SBI interest rate.

$\mathrm{H}$ 2: The Variable Underwriting Ratio has a Sig value of 0.0250 .05 , indicating that it has a positive and significant effect on the SBI interest rate.

\section{Test for Simultaneous Hypothesis (Test F)}

The $\mathrm{F}$ test results show that independent variables affect dependent variables with a significance of $5 \%$ or 0.05 when the $p$-value (in the Sig column) is less than the level of significance and $\mathrm{F}$ calculates greater than $\mathrm{F}$ table. 
The Impact of the Rupiah/Dollar Exchange Rate, Inflation Against the SBI Interest Rate During the New Normal Period

ANOVA $^{\text {b }}$
\begin{tabular}{|ll|l|l|l|l|l|}
\hline Model & & Sum of Squares & df & Mean Square & F & Sig. \\
\hline 1 & Regression &, 070 & 2 &, 035 & 6,948 &, $000^{\text {a }}$ \\
& Residual &, 044 & 36 &, 001 & & \\
& Total &, 114 & 38 & & & \\
\hline
\end{tabular}

a. Predictors: (Constant), INFLASI, KURS

b. Dependent Variable: SBI

Source: SPSS Data Processing Results

Based on the table above, a probability value (Sig) of 0.000 less than 0.05 indicates that the ratio of RP/USD and inflation rates together positively affect the SBI interest rate. When the value of $F$ calculates is compared to the value of $F$ table, it is known that when the value of $\mathrm{F}$ calculates is greater than the value of $\mathrm{F}$ table $(6,948>3.08)$, the ratio of RP / Dollar and inflation both positively affect the SBI interest rate."

H3: During The New Normal, the exchange rate/dollar and the inflation rate both have a positive effect on SBI interest rates.

\section{Determination Coefficient Test}

The adjusted $R$ Square should be used for multiple linear regression. $R$ Square is the value. Because the value of $R$ Square ranges from 0 to 1 , it is said to be good if it is greater than 0.05 . The coefficient of determination results in this study are as follows:

Model Summary ${ }^{\text {b }}$
\begin{tabular}{|l|l|l|l|l|}
\hline Model & $R$ & R Square & $\begin{array}{l}\text { Adjusted } \\
\text { Square }\end{array}$ & $\begin{array}{l}\text { Std. Error of the } \\
\text { Estimate }\end{array}$ \\
\hline 1 &, $785^{\text {a }}$ &, 617 &, 595 &, 03480 \\
\hline
\end{tabular}

a. Predictors: (Constant), INFLASI, KURS

b. Dependent Variable: SBI

Source: SPSS Data Processing Results

The adjusted coefficient of determination (R2) (R Square) is 0.595, according to the diats table. This means that independent variables, such as the $\mathrm{rp} /$ dollar rate and the inflation rate, influence 59.5 percent of the dependent variable SBI interest rate, while the remaining 40.5 percent ( 100 percent -59.5 percent) is influenced by variables other than the variables used in this study.

\section{F. CONCLUSION}

The following conclusions can be drawn based on the results of the data analysis that has been described:

1. The rupiah / dollar exchange rate has a positive and significant effect on SBI interest rates" during the New Normal period means "the exchange rate plays an important role in foreign and domestic trade, so the conclusion obtained from the study's results is obtained conformity between the theory and the study's results, that the variable Rupiah Exchange Rate against the US Dollar has a positive influence on interest rates in Indonesia."

2. Inflation has a positive and significant effect on SBI interest rates during the New Normal period, which means that inflation is consistent with the theory of a sustainable general price increase in an economy, with this relating to SBI interest rates on loan funds fees.

3. The SBI Interest Rate is positively influenced by the exchange rate / dollar and the inflation rate at the same time. During the New Normal period, the dollar rate, inflation rate, and compatibility between theory and research results have a large influence on the SBI interest rate and the compatibility between theory and research results that play an important role in trade both abroad and domestically.

\section{REFERENCES}

1) Ika Fahrika, J. R. (2020). Dampak Pandemi covid 19 Terhadap Perkembangan Makro Ekonomi di Indonesia Dan Respon Kebijakan Yang Ditempuh The Impact of The Co.

http://webcache.googleusercontent.com/search?q=cache:xBTOPOMUv1QJ:journal.feb.unmul.ac.id/index.php/INOVASI/ article/download/8255/1092+\&cd=5\&hl=id\&ct=clnk\&gl=id 
The Impact of the Rupiah/Dollar Exchange Rate, Inflation Against the SBI Interest Rate During the New Normal Period

2) Agung, M. (2011). Analisis Pengaruh Nilai Tukar Rupiah/US Dollar dan Tingkat Suku Bunga SBI Terhadap Indeks Harga Saham Gabungan di Bursa Efek IndonesiaTahun 2007-2009. Universitas Sumatera Utara. Medan.

3) Bank Indonesia : www.bi.go.id dan http://id.wikipedia.org/wiki/Sertifiikat Bank Indonesia

4) Bursa Efek Indonesia : www.idx.co.id dan www.finance.yahoo.com

5) Fahmi, Irham.(2012). Manajemen Investasi.Jakarta: Salemba Empat.

6) Ghozali, Imam. (2005). Aplikasi Analisis Multivariate Dengan Program SPSS. Universitas Diponegoro Semarang.

7) Ikhsan, Muhammad. (2010). Analisis Pengaruh Tingkat Suku Bunga SBI, Kurs Dollar AS, Pertumbuhan Ekonomi Indonesia dan Pertumbuhan Ekonomi AS Terhadap Indeks Harga Saham Gabungan (IHSG). Universitas Sumatera Utara Medan.

8) Murni, Anggia. (2010). Pengaruh Tingkat Suku Bunga SBI,Nilai Tukar Rupiah, dan Tingkat Inflasi Terhadap Indeks Harga Saham Gabungan di Bursa Efek Indonesia. Universitas Sumatera Utara Medan. 